\title{
Studies on Isolated Smooth Muscle Cells. IX. Application of Papain for Isolation of Single Smooth Muscle Cells from Guinea-pig Taenia Coli
}

\author{
Masayuki Hasegawa, Mamoru Kobayashi, Hideto Oyamada, \\ Tomoko Kamishima, Chieko Yoshida, Hisayuki OHata, Ikuo \\ Maruyama, Kazutaka Momose and Yasuo Gomi* \\ University of Showa, School of Pharmaceutical Sciences, 1-5-8 Hatanodai, \\ Shinagawa, Tokyo 142 and *Department of Pharmacology, Faculty of \\ Pharmaceutical Sciences, Kanazawa University, 13-1 Takaramachi, Kanazawa \\ 920, Japan
}

\begin{abstract}
Masayuki Hasegawa, Mamoru Kobayashi, Hideto Oyamada, Tomoko Kamishima, Chieko Yoshida, Hisayuki Ohata, Ikuo Maruyama, Kazutaka Momose and Yasuo Gomi. Studies on isolated smooth muscle cells. IX. Application of papain for isolation of single smooth muscle cells from guinea pig taenia coli. Jpn. J. Smooth Muscle Res. 1987, 23 (1), 3546. - To prepare single smooth muscle cells from the taenia coli of guinea pig, the application of papain to the enzymatic solution was examined under two conditions : 1) the isolation in a modified Tyrode solution (containing $0.18 \mathrm{mM} \mathrm{Ca}^{2+}: 0.18 \mathrm{mM} \mathrm{Ca}^{2+}$-Tyrode solution) and 2) the isolation in a high- $\mathrm{K}^{+}$Tyrode solution $\left(\mathrm{Na}^{+}\right.$was replaced by $\mathrm{K}^{+}$, and $\mathrm{Ca}^{2+}$ was not added: high- $\mathrm{K}^{+}$Tyrode solution). The presence of papain during collagenase digestion reduced contamination of broken cells and cell debris. In the case of the high- $\mathrm{K}^{+}$ Tyrode solution, papain increased the yield of single cells significantly. The cells were contracted in a dose-dependent manner by $\mathrm{Ca}^{2+}$ in the high- $\mathrm{K}^{+}$Tyrode solution and by carbachol in $0.18 \mathrm{mM} \mathrm{Ca}^{2+}$-Tyrode solution; furthermore, the contractions were antagonized by verapamil and atropine, respectively. Treatment with papain did not affect cell sensitivity to the stimulants. Therefore, our results suggest that the addition of papain is useful for the isolation of single cells to investigate the physiological and pharmacological characteristics of smooth muscle.
\end{abstract}

Key words: single cells ; taenia coli ; collagenase ; papain ;

\section{Introduction}

Some of the distinctive features of single cells have proved advantageous for investigation

Accepted for publication, March 26, 1987

長谷川雅之, 小林 護, 小山田英人, 神島智子, 吉田千恵子, 大幡久之, 丸山郁夫, 百瀬和享, 五味 保男*： 昭和大学薬学部薬理学教室 $\mathrm{T} 142$ 東京都品川区旗の台 1-5-8

* 金沢大学薬学部薬物学教室 7920 金沢市宝町 13-1 
of the contractile mechanisms of smooth muscle. The elimination of extracellular spaces, for example, makes it easier to determine ion fluxes during contraction or relaxation. The intrinsic activities of smooth muscle can also be detected without contributions of cell-to-cell interactions. Thus, the cells isolated from the stomach of the amphibian, Bufo marinus, have been utilized for various studies (Bagby et al., 1971; Bagby and Fisher 1973; Fay and Delise, 1973 ; Honeyman et al., 1978; Fay et al., 1983 ; Scheid and Fay, 1984 a, 1984 b; Sims et al., 1985). With regard to the cells of mammalian origin, Momose et al. $(1978 ; 1979 ; 1980 ; 1983)$ have examined the isolation procedures and obtained the cells which respond to various agonists. However, it has also been proven that mammalian smooth muscle cells are difficult to isolate, and the yield of viable cells is not sufficient for biochemical studies. Therefore, the establishment of a reliable isolation procedure is necessary in order to obtain a large amount of viable cells constantly.

On the other hand, in commercially available collagenase preparations, several peptidases have been found to be contaminated, and their activities varied from lot to lot. In our experiments, collagenase preparations with higher activities of contaminants provided larger numbers of single cells.

Therefore, we introduced papain, a peptidase with a broad spectrum, into collagenase digestion in order to isolate single cells although a trypsin inhibitor has been used for the stomach of Bufo marinus (Bagby and Fisher, 1973 ; Fay and Delise 1973 ; Sims et al, 1985). In this report, we present a newly developed isolation procedure as well as morphological and pharmacological properties of single smooth muscle cells from the taenia coli of guinea pig provided by this revised method.

\section{Materials and methods}

\section{Experimental animals}

Guinea pigs (Hartley, either male or female weighing 300-600 g) were used.

\section{Materials}

Collagenase (Type I), papain (Type II), bovine plasma albumin (fraction V) and carbachol $(\mathrm{CCh})$ were purchased from Sigma Chemical Co. HEPES (N-2-hydroxyethylpiperazine- $\mathrm{N}^{\prime}-2-$ ethanesulfonic acid) was obtained from Nakarai Chemicals, Ltd.

\section{Preparation of single cells from taenia coli of guinea pig}

a) Preparation in the high- $\mathrm{K}^{+}$Tyrode solution

Guinea pig was stunned by a blow and the taenia coli was removed carefully. The tissue was immersed in $50 \mathrm{~m} l$ of a Tyrode solution $\left(137 \mathrm{mM} \mathrm{NaCl}, 2.7 \mathrm{mM} \mathrm{KCl}, 1.8 \mathrm{mM} \mathrm{CaCl}_{2}, 1.0 \mathrm{mM}\right.$ $\mathrm{MgCl}_{2}, 5.6 \mathrm{mM}$ glucose and 4.2 mM HEPES, pH 7.4: Tyrode solution) for 90 minutes. The medium was aerated continuously. Next the medium was replaced by a $\mathrm{Ca}^{2+}$-free Tyrode solution $\left(137 \mathrm{mM} \mathrm{NaCl}, 2.7 \mathrm{mM} \mathrm{KCl}, 1.0 \mathrm{mM} \mathrm{MgCl}_{2}, 5.6 \mathrm{mM}\right.$ glucose and $4.2 \mathrm{mM}$ HEPES, pH $7.4: \mathrm{Ca}^{2+}$-free Tyrode solution), and the tissue was incubated for 30 minutes. Subsequently, the tissue was transferred to the high- $\mathrm{K}^{+}$Tyrode solution $(140 \mathrm{mM} \mathrm{KCl}, 1.0 \mathrm{mM} \mathrm{MgCl}, 5.6 \mathrm{mM}$ glucose and 4.2 mM HEPES, pH 7.4 : high- $\mathrm{K}^{+}$Tyrode solution). The tissue was then minced 
and suspended in $2.0 \mathrm{~m} l$ of the high- $\mathrm{K}^{+}$Tyrode solution containing $0.2-0.6 \%$ collagenase (since specific activity of collagenase varied for each preparation, optimum concentrations were determined in preliminary experiments) and 1.0\% bovine plasma albumin. In some experiments, papain ( 30.0 units $/ \mathrm{m} l$ ) was added to an enzymatic medium. The mince was incubated for 30 minutes with gentle stirring. To terminate the digestion, the mince was centrifuged twice (when the revolution reached 1,000 per minute, the centrifuge was turned off). The precipitate was resuspended in a $4 \mathrm{~m} l$ high- $\mathrm{K}^{+}$Tyrode solution without bovine plasma albumin, and the cells were dispersed by pipetting gently with a wide bore pipette. All the procedures were carried out at $37^{\circ} \mathrm{C}$ except centrifugations.

b) Preparation in the $0.18 \mathrm{mM} \mathrm{Ca}^{2+}$-Tyrode solution

The taenia coli of guinea pig was dissected carefully and immersed in the $0.18 \mathrm{mM} \mathrm{Ca}^{2+}$ Tyrode solution ( $137 \mathrm{mM} \mathrm{NaCl}, 2.7 \mathrm{mM} \mathrm{KCl}, 0.18 \mathrm{mM} \mathrm{CaCl}_{2}, 1.0 \mathrm{mM} \mathrm{MgCl}_{2}, 5.6 \mathrm{mM}$ glucose and $4.2 \mathrm{mM}$ HEPES, pH 7.4: $0.18 \mathrm{mM} \mathrm{Ca}^{2+}$-Tyrode solution). The medium was refreshed every 30 minutes, and the tissue was incubated for 90 minutes. The following steps were carried out under the same conditions as the high $-\mathrm{K}^{+}$Tyrode solution.

\section{Cell count}

The cell suspension was passed through a nylon mesh $(200 \mu \mathrm{m})$, and the number of cells was counted with an eosinophil counter. Using a phase contrast microscope for observation, the cells which seemed to have no morphological damages were designated as intact cells. The yield of single cells was expressed as the number of cells obtained from $1 \mathrm{mg}$ of the tissue (wet weight).

\section{Contraction of single cells by $\mathrm{Ca}^{2+}$ or $\mathrm{CCh}$}

The cell suspension was divided into several experimental tubes. Stimulants of various concentrations were added, and the cells were fixed by glutaraldehyde. Longitudinal length of the cells was estimated photographically. Antagonists were added 5 minutes before the challenge of agonists.

\section{Contraction of intact tissue by $\mathrm{Ca}^{2+}$ or $\mathrm{CCh}$}

The tissue was suspended in an organ bath filled with an incubation medium at $37^{\circ} \mathrm{C}$. Contraction was recorded isotonically with an isotonic transducer (Nihon Kohden, TD-112S). The loading tension was $200 \mathrm{mg}$.

\section{Results}

1. Morphological and pharmacological properties of single smooth muscle cells prepared in high- $K^{+}$Tyrode solution

Fig. 1A represents phase contrast micrograph of single smooth muscle cells isolated from the taenia coli of guinea pigs by collagenase alone in the high- $\mathrm{K}^{+}$Tyrode solution. The intact cells were spindle-shaped and their surface was smooth. The length and width of the cells ranged from 70 to $307 \mu \mathrm{m}(178.8 \pm 4.6 \mu \mathrm{m}, \mathrm{n}=107)$ and from 5 to $10 \mu \mathrm{m}$, respectively. However, large amounts of cell fragments and broken cells contaminated the preparations. Some of the 

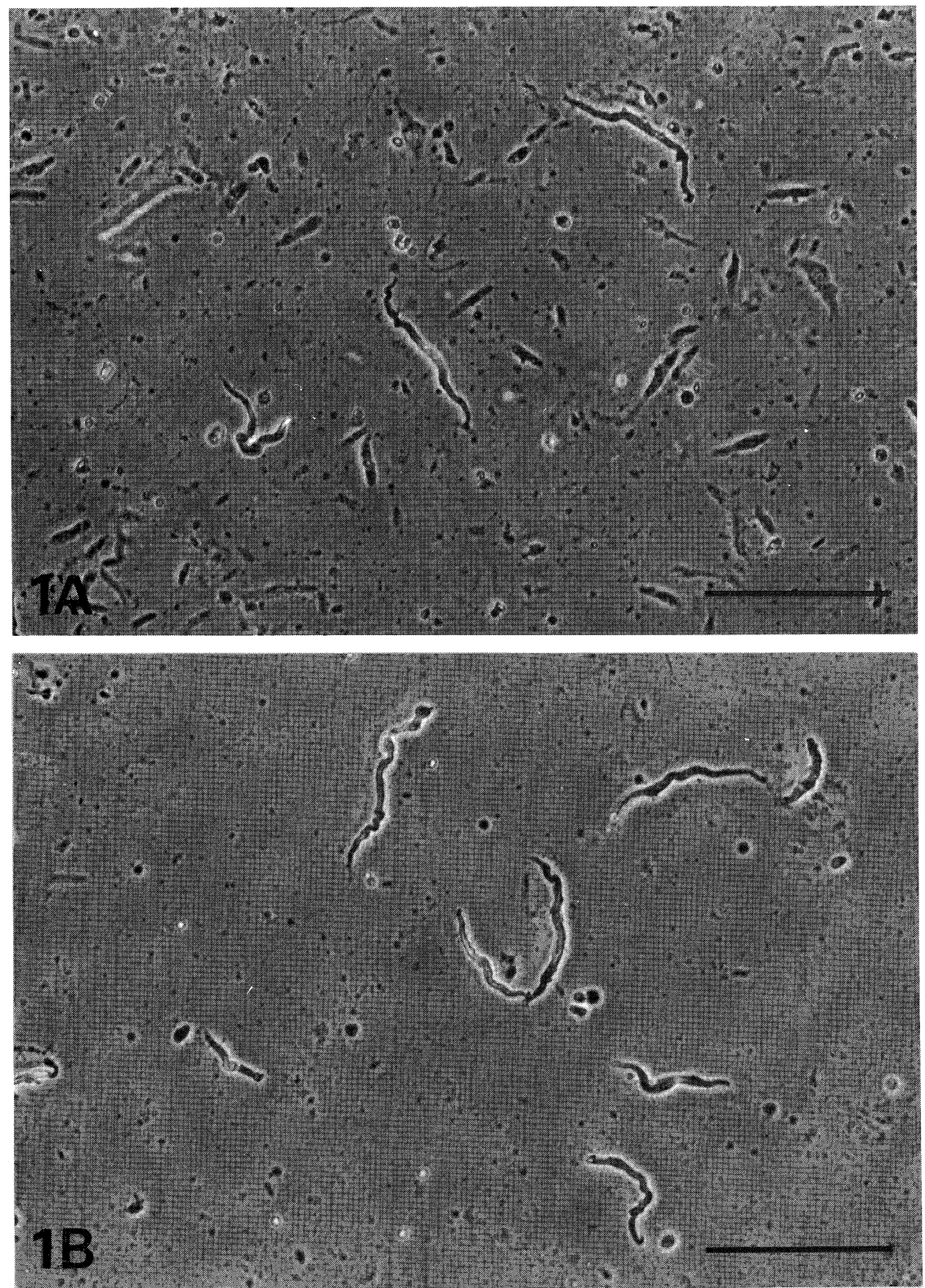

Fig. 1. Phase contrast micrographs of single smooth muscle cells isolated in the high- $\mathrm{K}^{+}$ Tyrode solution. A : the cells isolated by collagenase alone. B : the cells isolated by collagenase and papain. Scale represents $200 \mu \mathrm{m}$.

cells obtained by this treatment seemed to be already contracted.

Various concentrations of papain were examined in order to prepare single cells, and the results suggested that approximately $30 \mathrm{units} / \mathrm{m} l$ of papain was most effective (Yoshida et al., 1986). Table 1 shows that the application of papain increased the yield of the cells significantly, although the degrees varied in each experiment. Fig. 1B represents the cells prepared by the combination of collagenase and papain. Neither size nor shape of the cells 
Table 1. Effect of papain on the yield of single smooth muscle cells prepared in the absence of calcium ions

\begin{tabular}{|c|c|c|}
\hline Exp. & \multicolumn{2}{|c|}{$\begin{array}{l}\text { Number of single cells } / \mathrm{mg} \text { tissue (wet wt.) } \\
\begin{array}{ll}\text { control } & \text { with papain }(30 \text { units } / \mathrm{m} l)\end{array}\end{array}$} \\
\hline 1 & 11,975 & $18,772(157)$ \\
\hline 2 & 9,901 & $16,132(163)$ \\
\hline
\end{tabular}

Minced taenia coli were incubated in the high- $\mathrm{K}^{+}$ Tyrode solution with collagenase in the presence or absence of papain for $30 \mathrm{~min}$. at $37^{\circ} \mathrm{C}$. The minces were then agitated by pipetting for dispersion of smooth muscle cells. The yields of the cells isolated by two enzymes are represented as the percentage of the control in parentheses. See text for details.

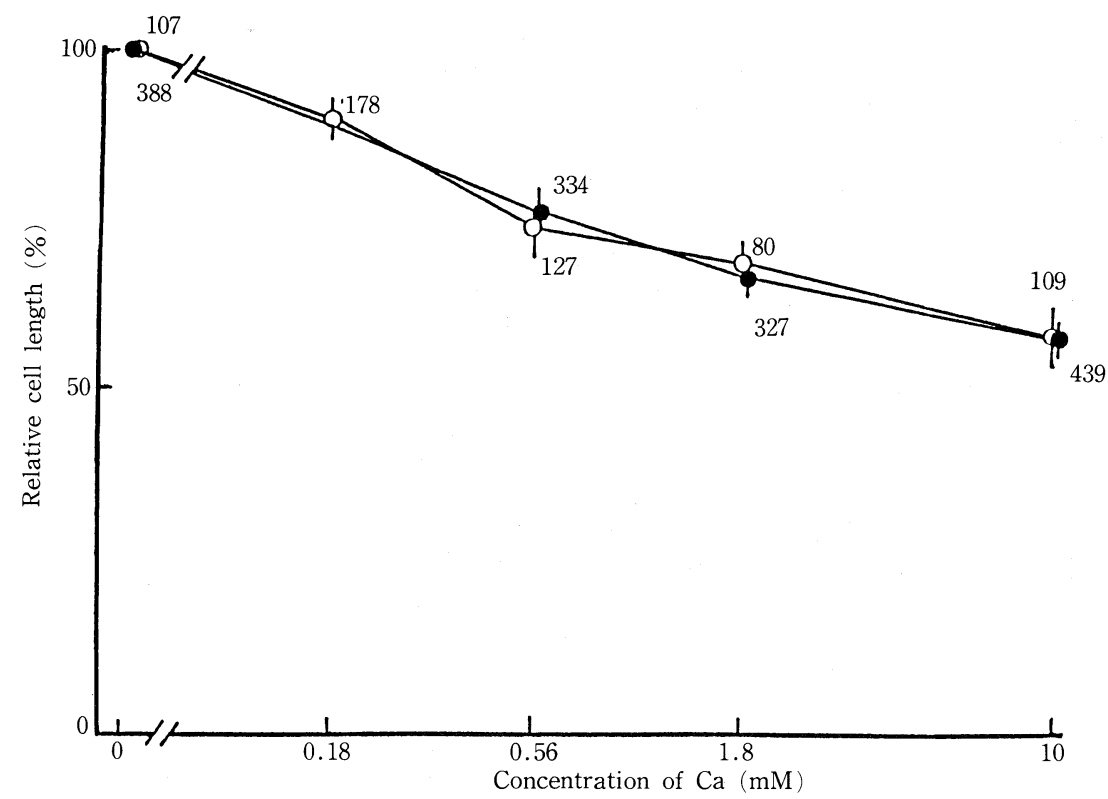

Fig. 2. Dose-response relationship between the concentration of $\mathrm{Ca}^{2+}$ and the cell length. Numbers stand for cell numbers, and vertical bars show S.E.M. The cell length is represented as percentage of the control. Single smooth muscle cells were isolated by digestion with collagenase in the presence $(-\mathrm{O}-)$ and absence $(--)$ of papain. Cell suspension was divided into 5 tubes and aliquots were incubated with various concentrations of $\mathrm{Ca}^{2+}$ for 75 seconds. Subsequently, the cells were fixed by $1 \%$ glutaraldehyde. All experiments were carried out at $37^{\circ} \mathrm{C}$. The length of each cell was determined photographically.

was significantly different from their counterpart prepared by collagenase alone. The contamination of the cell fragments and the broken cells was reduced by the addition of papain.

Fig. 2 depicts the contractions of the cells induced by $\mathrm{Ca}^{2+}$. The threshold of the $\mathrm{Ca}^{2+}$ concentration was $0.18 \mathrm{mM}$, and the cells became shorter as the concentration of $\mathrm{Ca}^{2+}$ increased. In this experiment, concentration over $10 \mathrm{mM}$ was not examined since at the higher concentration, the contraction might be evoked by osmotic pressure. Hence, concentrations 

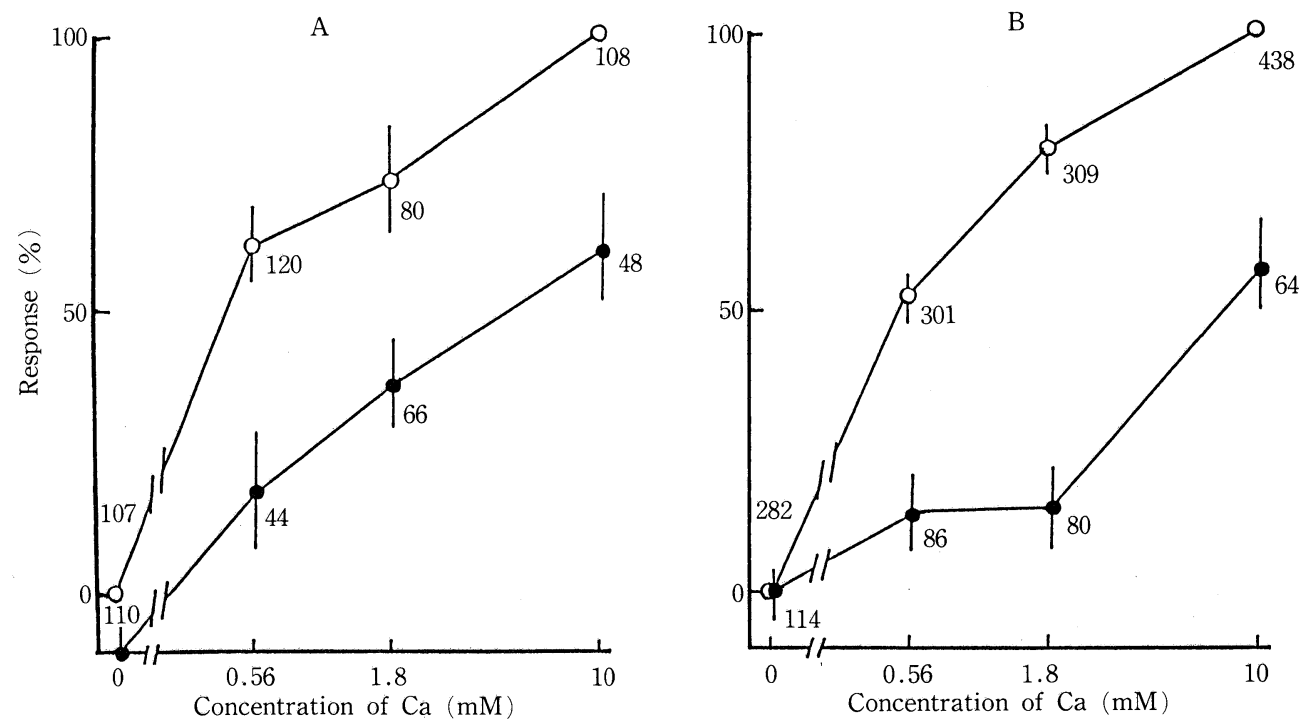

Fig. 3. Effect of verapamil on $\mathrm{Ca}^{2+}$ contraction of single smooth muscle cells. Cells were preincubated with (--) or without (-○-) $2 \mathrm{mM}$ verapamil for 5 minutes, then mixed with various concentrations of $\mathrm{Ca}^{2+}$. $\mathrm{A}$ : the cells isolated by collagenase alone. $\mathrm{B}$ : the cells isolated by collagenase and $30 \mathrm{units} / \mathrm{ml}$ papain. Vertical bars represent S.E.M. Detailed conditions were the same as described in the Fig. 2 legend.

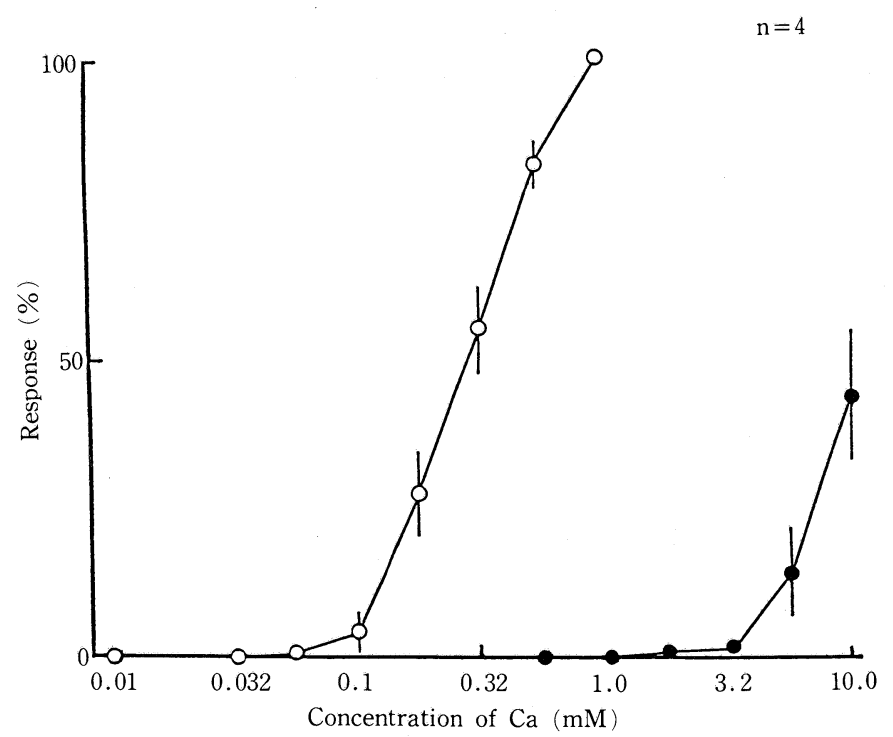

Fig. 4. $\mathrm{Ca}^{2+}$ contraction of taenia coli of guinea pig in the high- $\mathrm{K}^{+}$Tyrode solution and its inhibition by verapamil. Tissue was suspended in an organ bath filled with $10 \mathrm{ml}$ of the high- $\mathrm{K}^{+}$Tyrode solution and the tension was loaded at $200 \mathrm{mg}$. The response was recorded isotonically. $\mathrm{Ca}^{2+}$ was added cumulatively and $2 \mathrm{mM}$ verapamil was added 5 minutes before the first challenge of $\mathrm{Ca}^{2+}$. The incubation was carried out at $37^{\circ}$. Vertical bars represent S.E.M. - - -control, - - with $2 \mathrm{mM}$ verapamil. 
for maximum response and half the maximum response were not available. With respect to the dose-response curve, there was no significant difference between the preparations isolated by collagenase alone and by collagenase and papain. Thus, our result suggests that papain did not affect the $\mathrm{Ca}^{2+}$ sensitivity of single cells.

Fig. 3 shows that the $\mathrm{Ca}^{2+}$ contractions were inhibited significantly by verapamil in both preparations (treated with collagenase alone and with the combination of collagenase and
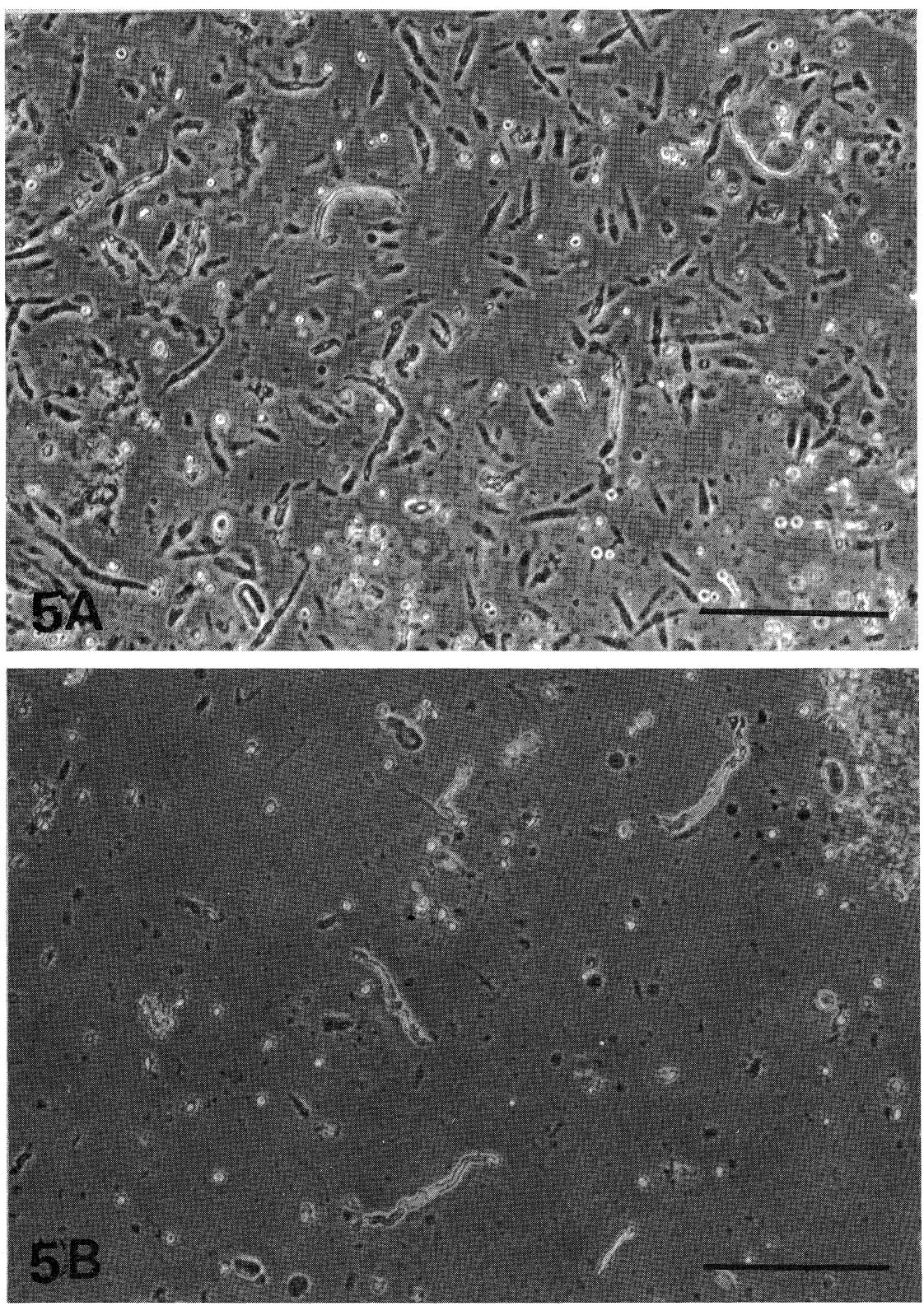

Fig. 5. Phase contrast micrographs of single smooth muscle cells isolated in the $0.18 \mathrm{mM}$ $\mathrm{Ca}^{2+}$-Tyrode solution. $\mathrm{A}$ : the cells isolated by collagenase alone. $\mathrm{B}$ : the cells isolated by collagenase and papain. Scale represents $200 \mu \mathrm{m}$. 
papain). Though $2 \mathrm{mM}$ verapamil antagonized the $\mathrm{Ca}^{2+}$ contraction of the tissue significantly as depicted in Fig. 4, it did not affect the length of resting cells in either preparation. In spite

Table 2. Effect of papain on the yield of single smooth muscle cells prepared in the presence of 0.18 $\mathrm{mM} \mathrm{Ca}{ }^{2+}$

\begin{tabular}{|c|c|c|}
\hline Exp. & \multicolumn{2}{|c|}{$\begin{array}{l}\text { Number of single cells } / \mathrm{mg} \text { tissue (wet wt.) } \\
\begin{array}{ll}\text { control } & \text { with papain ( } 30 \text { units } / \mathrm{m} l)\end{array}\end{array}$} \\
\hline 1 & 42 & $288 \quad(686)$ \\
\hline 2 & 90 & 905 (1006) \\
\hline 3 & 215 & $217 \quad(101)$ \\
\hline 4 & 200 & $215 \quad(108)$ \\
\hline 5 & 369 & (29) \\
\hline 6 & 908 & (31) \\
\hline 7 & 324 & $449 \quad$ (139) \\
\hline
\end{tabular}

Minced taenia coli were incubated in the $0.18 \mathrm{mM} \mathrm{Ca}^{2+}$ Tyrode solution with collagenase in the presence or absence of papain for $30 \mathrm{~min}$. at $37^{\circ} \mathrm{C}$. The minces were then agitated by pipetting for dispersion of smooth muscle cells. The yields of the cells isolated by two enzymes are represented as the percentage of the control in parentheses. See text for details.

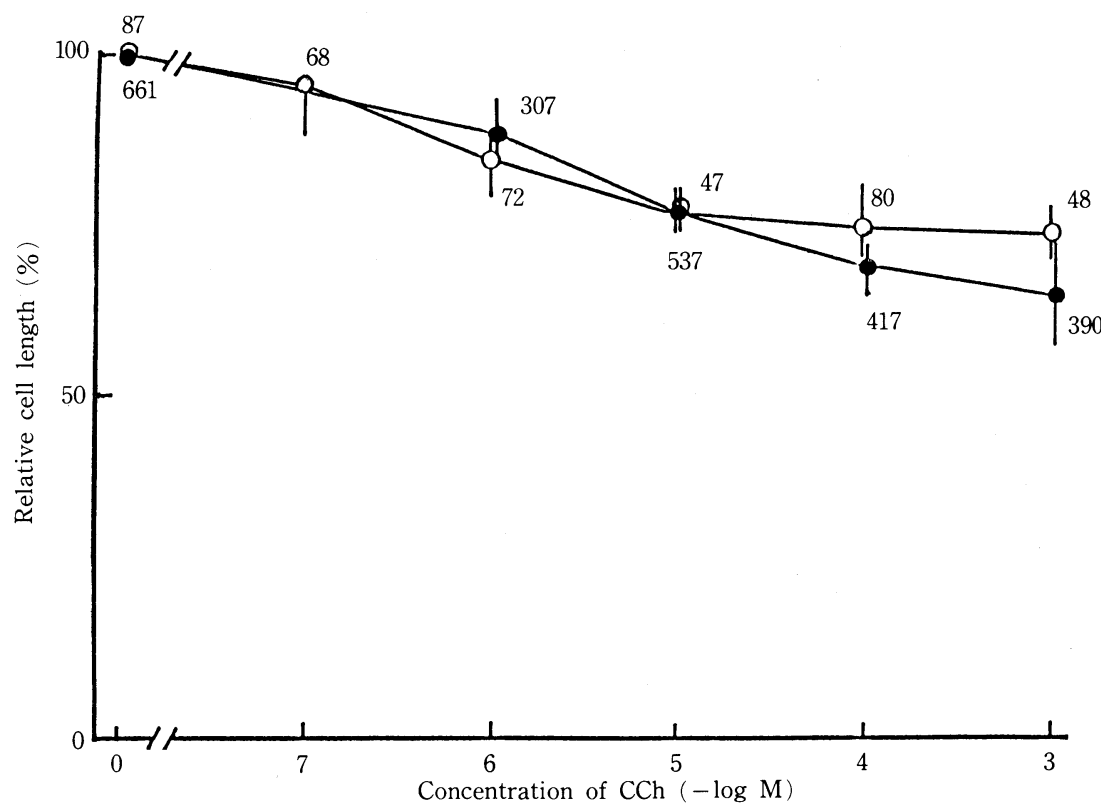

Fig. 6 Dose-response relationship between the concentration of $\mathrm{CCh}$ and the cell length. Numbers stand for cell numbers, and vertical bars show S.E.M. The cell length is represented as percentage of the control. Single smooth muscle cells were isolated by digestion with collagenase in the presence (- - ) and absence $\left(-0_{-}\right)$of papain. Cell suspension was divided into 6 tubes and aliquots were incubated with various concentrations of $\mathrm{CCh}$ for 75 seconds. Subsequently, the cells were fixed by $1 \%$ glutaraldehyde. All experiments were carried out at $37^{\circ} \mathrm{C}$. The length of each cell was determined photographically. 


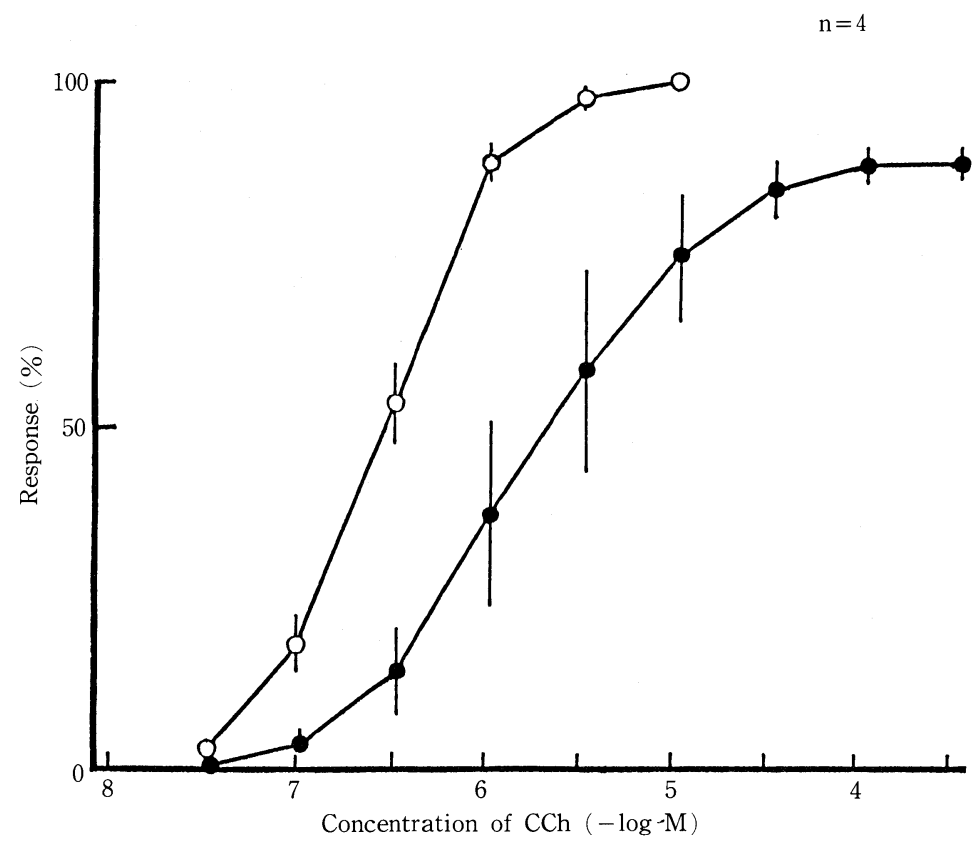

Fig. 7 CCh contraction of taenia coli of guinea pig in the $0.18 \mathrm{mM} \mathrm{Ca}^{2+}$-Tyrode solution and its inhibition by atropine. Tissue was suspended in an organ bath filled with $10 \mathrm{~m} l$ of the $0.18 \mathrm{mM} \mathrm{Ca} \mathrm{Ca}^{2+}$-Tyrode solution and the tension was loaded at $200 \mathrm{mg}$. The response was recorded isotonically. CCh was added cumulatively and $10 \mu \mathrm{M}$ atropine was added 5 minutes before the first challenge of CCh. The incubation was carried out at $37^{\circ} \mathrm{C}$. Vertical bars represent S.E.M. - - - control, -- with $10 \mu \mathrm{M}$ atropine.

of this fact, verapamil inhibited the contraction induced by $\mathrm{Ca}^{2+}$, and the dose-response curve shifted to the right in a parallel manner. Therefore, this suggests that competitive inhibition of $\mathrm{Ca}^{2+}$ entry occurred through voltage dependent channels in the cell preparations.

2. Morphological and pharmacological properties of single smooth muscle cells prepared in the $0.18 m M \mathrm{Ca}^{2+}$-Tyrode solution

Phase contrast micrographs of the single cells isolated in the $0.18 \mathrm{mM} \mathrm{Ca}^{2+}$-Tyrode solution are represented in Fig. 5. The cells in Fig. 5A and 5B were prepared with collagenase alone and with the combination of collagenase and papain, respectively. Lengths of the single cells isolated by collagenase alone and by collagenase and papain were $70.4 \pm 2.6 \mu \mathrm{m}(\mathrm{n}=87)$ and $87.4 \pm 1.3 \mu \mathrm{m}(\mathrm{n}=661)$, respectively. The cells isolated in the $0.18 \mathrm{mM} \mathrm{Ca}^{2+}$-Tyrode solution were shorter than those prepared in the high- $\mathrm{K}^{+}$Tyrode solution, although marked differences between the two preparations were not observed with a phase contrast microscope. The contamination of broken cells and cell fragments was remarkably reduced by treatment of collagenase and papain. In the $0.18 \mathrm{mM} \mathrm{Ca}^{2+}$-Tyrode solution, the yields of single cells varied and papain did not increase the yields as shown in Table 2.

Fig. 6 shows the dose-response relationships between the concentration of $\mathrm{CCh}$ and the contraction of the cells. The cells prepared with collagenase alone became shorter as the concentration of $\mathrm{CCh}$ increased, and the maximum response was obtained at $10 \mu \mathrm{M} \mathrm{CCh}$. At 

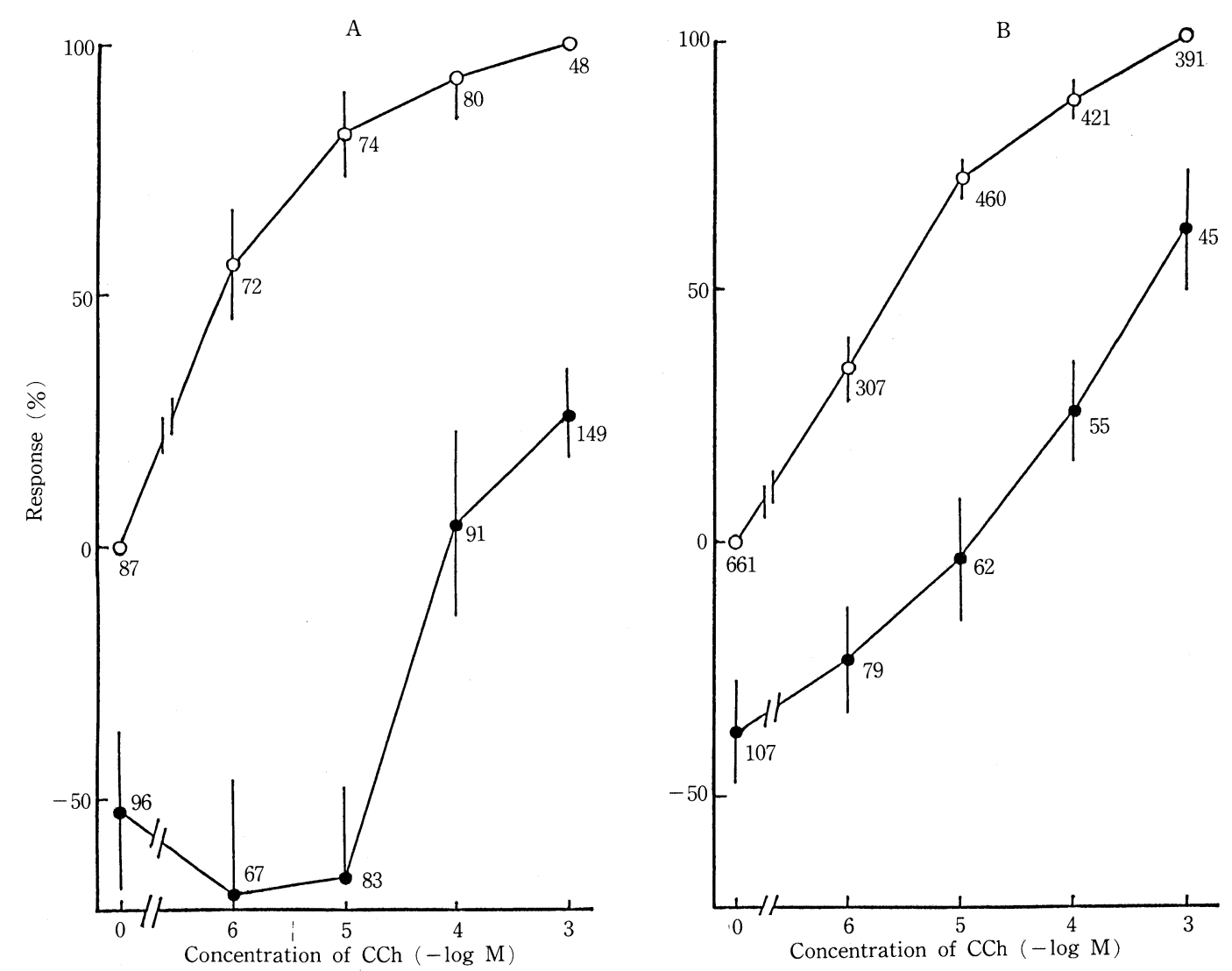

Fig. 8. Effect of atropine on CCh contraction of single smooth muscle cells. Cells were preincubated with (- - ) or without (-○-) $10 \mu \mathrm{M}$ atropine for 5 minutes, then mixed with various concentrations of $\mathrm{CCh}$. A : the cells isolated collagenase alone. B: the cells isolated by collagenase and 30 units $/ \mathrm{m} l$ papain. Vertical bars represent S.E.M. Detailed conditions were the same as described in the Fig. 6 legend.

this concentration, the length of the cells was $70.5 \pm 2.7 \%(\mathrm{n}=48)$ of the original size. The application of papain did not affect the cell sensitivity to CCh. The addition of $10 \mu \mathrm{M}$ atropine, which inhibited contraction of intact tissue greatly as shown in Fig. 7, relaxed the cells at a resting state and antagonized $\mathrm{CCh}$ contraction competitively as shown in Fig. 8A. Fig. 8B describes that papain did not change the sensitivities of the single cells to $\mathrm{CCh}$ or atropine.

\section{Discussion}

The yield and viability of single cells of guinea pig taenia coli were dependent on amount of contaminated peptidases in commercially available collagenase preparations. Therefore, we examined introduction of papain to the incubation medium. On the other hand, as Momose and Gomi (1979) pointed out, isolation of single smooth muscle cells from the mammalian smooth muscle in a high- $\mathrm{K}^{+}$solution was much easier than in a physiological salt solution. However, isolation of the cells under physiological conditions was also required to study various characteristics of single smooth muscle cells. Therefore, we examined the effects of papain under two conditions : 1) isolation of cells in a high- $\mathrm{K}^{+}$Tyrode solution, and 2) isola- 
tion of cells in a $0.18 \mathrm{mM} \mathrm{Ca}^{2+}$-Tyrode solution. Lower concentration of $\mathrm{Ca}^{2+}$ in the Tyrode solution proved to be beneficial because determination of cell contractions was easier under this condition, and there was no change in cell sensitivities (Momose and Gomi, 1978). In the present experiments, papain $(30$ units $/ \mathrm{m} l$ ) increased the number of dispersed cells in the high$\mathrm{K}^{+}$Tyrode solution (Table 1). It is well known that collagen fibers tightly connect visceral cells to each other and nothing but collagenase can digest the fibers. Hence, the reason that collagen fibers were well digested by the combination of two enzymes might be as follows: In the first step, collagenase breaks down the helix structure of collagen fibers, and then papain digests the peptide bonds. However, the enzymatic digestion seems not to break the fibers completely because mechanical agitation is also necessary to disperse the cells.

The combination of collagenase and papain reduced contamination of the broken cells and the cell fragments in the high- $\mathrm{K}^{+}$Tyrode solution. It is probable that the better digestion by papain preserved the cells from being torn during mechanical agitation with a pipette.

It is generally accepted that $\mathrm{Ca}^{2+}$ is compulsory for collagenase activation. In our studies, however, $\mathrm{Ca}^{2+}$ was not added to the high- $\mathrm{K}^{+}$Tyrode solution whereas cells were well dispersed. In light of this fact, very little $\mathrm{Ca}^{2+}$ contaminating the medium might be enough to activate collagenase.

In case of the $0.18 \mathrm{mM} \mathrm{Ca}^{2+}$-Tyrode solution, papain did not increase the number of single cells. Since $\mathrm{Ca}^{2+}$ suppresses papain activity, digestion of collagen fibers might be less than in the case of the high- $\mathrm{K}^{+}$Tyrode solution. Therefore, it is recommended that cells should be prepared in a lower $\mathrm{Ca}^{2+}$ medium and transferred to physiological salt solutions.

As described previously, papain decreased contamination of cell fragments and broken cells (Fig. 1B and Fig. 5B). Any other methods such as centrifugation could not remove the broken cells and the cell debris from the cell suspension. In the study of $\mathrm{Ca}^{2+}$ fluxes, such contaminants will disturb determination of genuine ion movement due to phosphate ions which leak from the broken cells and combine with $\mathrm{Ca}^{2+}$. Therefore, introduction of papain to the cell isolation is useful to study ion movements. In the high- $\mathrm{K}^{+}$Tyrode solution, papain increased the yield of the cells by $50 \%$ (Table 1). Although this value is not overwhelming, the increase in cell number may contribute to investigate ion fluxes which demand larger amounts of intact cells. However, it should also be noted that cell sensitivity to atropine was altered by treatment with collagenase (Figs. 7 and 8); and as Momose and Gomi (1979) have already mentioned, the cells dispersed by collagenase partly lost their sensitivity to $\mathrm{Ca}^{2+}$ (Figs. 3 and 4). The changes in sensitivity might be related to the alternation of the membrane properties brought by digestion; therefore, further studies should be performed.

\section{References}

Bagby, R.M. and Fisher, A. (1973). Graded contractions in muscle strips and single cells from Bufo marinus stomach. Am. J. Physiol. 225 : 105-109

Bagby, R.M., Young, A.M., Dotson, R.S., Fisher, B.A. and McKinnon, K. (1971). Contraction of single smooth muscle cells from Bufo marinus stomach. Nature 234: 351-352

Fay, F.S. and Delise, C.M. (1973). Contraction of isolated smooth muscle cells-Structure changes. Proc. Nat. Acad. Sci. 70 : 641-645

Fay, F.S., Fujiwara, K., Rees, D.D. and Fogarty, K.E. (1983). Distribution of alpha-actinin in single 
smooth muscle cells. J. Cell Biol. 96 : 783-795

Fay, F.S. and Singer, J.J. (1977). Characteristics of response of isolated smooth muscle cells to cholinergic drug. Am. J. Physiol. 232 : C144-C154

Honeyman, T., Merriam, P. and Fay, F.S. (1978). The effects of isoproterenol on adenosine cyclic $3^{\prime}$, 5 -monophosphate and contractility in isolated smooth muscle cells. Mol. Pharmacol. 14 : $86-98$

Momose, K. and Gomi, Y. (1978). Studies on isolated smooth muscle cells. IV. Isolation and acetylcholine contraction of single smooth muscle cells from taenia coli of guinea pig. J. Pharm. Dyn. 1: 184-191

Momose, K. and Gomi, Y. (1979). Studies on isolated smooth muscle cells. V. Calcium and caffeine contraction. J. Pharm. Dyn. 2: 98-104

Momose, K. and Gomi, Y. (1980). Studies on isolated smooth muscle cells. VI : dispersion procedures for acetylcholine-sensitive smooth muscle cells of guinea pig taenia coli. Jap. J. Smooth Muscle Res. 16 : 29-36

Momose, K., Sato, M. and Gomi, Y. (1983). Studies on isolated smooth muscle cells. VIII. ${ }^{45}$ Ca-efux from single smooth muscle cells isolated from taenia coli of guinea pig. J. Pharm. Dyn. 6 : 441-448

Scheid, C.R. and Fay, F.S. (1984 a). Beta-adrenergic effects on transmembrane Ca fluxes in isolated smooth muscle cell. Am J. Physiol. 246 : C431-C438

Scheid, C.R. and Fay, F.S. (1984 b). Transmembrane ${ }^{45} \mathrm{Ca}$ fluxes in isolated smooth muscle cells: basal $\mathrm{Ca}^{2+}$ influxes. Am. J. Physiol. 246 : C422-C430

Sims, S.M., Singer, J.J. and Waslh, J.V. Jr. (1985). Cholinergic agonists suppress a potassimum current in freshly dissociated smooth muscle cells of the toad. J. Physiol. 367 : 503-529

Yoshida, C., Kobayashi, M., Maruyama, I. and Momose, K. (1986). Preparation of single smooth muscle cells by purified collagenase and papain. Jap. J. Pharmacol. 40:207P 